\title{
Editorial
}

\section{Aggression and Crime. An Introduction to a Hot-Topic}

\author{
J. Martin Ramirez* \\ Universidad Complutense Madrid, Spain
}

This special hot-topic issue arose from a symposium at the IV CICA-STR International Conference held in Cartagena de Indias (Colombia) in 2010, dealing on "Aggression, Political Violence, and Terrorism". In order to put the symposium within the general frame of the conference, the issue starts with the opening words of its Chairman, focused at some important general topics related to aggression and terrorism, with an special emphasis on the situation of security in Colombia, as well as some useful considerations on the impact of criminal justice.

Relationships between aggression and crime are analyzed from a quite pluridiscipllinary approach, dealing with neurosciences, psychology, and law. Its conducting thread is crime, either because of the sensitive topics analized -aggression, and some related constructs, as impulsivity, psychological or sexual harassment, and intimate violence at home and at work, or because of the specific kind of subjects studied -drug traffickers and reoffenders, on one side, or police officers, on the another one.

Roberto Mercadillo and Fernando Barrios introduce the issue offering an exploration of impulsivity in police officers. One of the problems identified in their behavior refers to some aggressive expressions linked with impulsive reactions. The performance of cognitive paradigms, analyzed by functional magnetic resonance imaging, were complemented and interpreted by ethnological observations and psychometrical evaluations. Their results suggest that inhibitory reactions and impulsivity are regulated by a functional neurocognitive system based on moral and behavioral codes learned during the police training and practice. Aggression detected in the police department is linked with the perception of unfair and discomfort in the police organization but not with impulsive factors.

The relation of this perception of unfair and discomfort to aggression is next presented in a wider context of justification for interpersonal aggression by Luis Millana and Martin Ramirez, analyzing the degree of acceptance of various forms of aggression in a variety of settings in young minor re-offenders serving in reformatories. Results showed that

*Address correspondence to this author at the Universidad Complutense Madrid, Spain; Tel: 34918444 695; Fax: 34913943 069;

E-mail: mramirez@med.ucm.es; Web: http://www.jmartinramirez.org the young delinquent population justified physical aggression at a higher level than 'normal' teenagers of similar age in virtually all situations, whereas no significant differences were found related to passive aggression or verbal emotional acts.

In 2009 György Virág and Katalin Parti conducted 'the Budapest research', focused on online activities and behaviour of teenagers of the capital of Hungary. The article contributed by them summarizes their own experimental research and that of others on a specific topic: the risk of online sexual abuse in several countries members of the European Union. One of the striking outcomes was that a significant proportion of the Hungarian teenagers seemed to be less embarrassed when confronting sexual material online or someone initiated indecent talk with them.

A second paper of Luis Millana is focused at a serious public health problem: domestic violence. He does it in a very positive way. After describing for both batterers serving in prison and for those with suspension of the sentence enforcement, Millana considers how they may help in their rehabilitation as well as in the protection of the battered partners.

Paz Toldos addresses the complex problem of psychological harassment in the workplace using two methods: the perceived victimization method and the perceived exposure to bullying behaviors method, and their combination. Her results suggest a perceived victimization of $19.5 \%$, an exposure to bullying behavior of $12.8 \%(\mathrm{~N}=221)$, and an $8.4 \%$ in the combination of both methods.

Finally, although it may seem a little bit out of place in this issue-it has little directly to do with the experimental approaches of the other articles-, the theoretical paper of Pilar Otero is potentially a very important contribution, because it adds a much needed legal dimension to the psychobiological approach of the rest of the issue, offering at least a chance that problems related to organized crime, such as drug trafficking and terrorism, will be solved. She deals with the criminal law area, as is the paradigm of a regulation at the limit of constitutional legitimacy, analysing the criminal justice reaction to this kind of crimes. Otero stresses the concern of a great part of society that feels being held prisoner by this violence, and reasonably suggests that legislators should attempt to find some solution, securing the incapacitation of the criminal as the only objective.

(C) J. Martin Ramirez; Licensee Bentham Open.

This is an open access article licensed under the terms of the Creative Commons Attribution Non-Commercial License (http://creativecommons.org/licenses/by-nc/3.0/) which permits unrestricted, non-commercial use, distribution and reproduction in any medium, provided the work is properly cited. 